\title{
The Reviewability of the Parliamentary Commissioner
}

\author{
Sheena N. McMurtrie*
}

The decision of the Queen's Bench Division [QBD] in $R$. v. Parliamentary Commissioner for Administration, Ex Parte Dyer ${ }^{1}$ appears to have clarified the position of the Parliamentary Commissioner [PCA] in relation to judicial review. ${ }^{2}$ In the Dyer case, Lord Justice Simon Brown held that "there was nothing about the commissioner's role nor the statutory framework within which he operated so singular as to take (him) wholly outside the purview of judicial review." This decision may raise more problems than it resolves.

First, the decision raises questions about the constitutional position of the office and its relationship with Parliament itself. The PCA is not technically an "ombudsman", although the title is popularly used. ${ }^{3}$ Although the office is independent of the government, the PCA is not as completely independent of all other bodies as the title of "ombudsman" would suggest. ${ }^{4}$ The office was created as an adjunct of Parliament. The PCA is accountable to Parliament through the duty to present an annual report. ${ }^{5}$ In contrast, the Commissioners for Local Administration [CLAs], for instance, report to other statutory bodies. ${ }^{6}$ The PCA can only be removed by an address to both Houses of Parliament. ${ }^{7} \mathrm{He}$ is frequently referred to as an officer of Parliament. ${ }^{8}$ In addition, complaints only reach him via the M.P.

\footnotetext{
* Lecturer in Law, the University of Buckingham. The author wishes to thank Francis Coleman for his helpful comments on a draft of this note, and Mike Radford for his initial input. Any errors remain the author's own.
}

1. [1994] 1 All E.R. 375; also [1994] I W.L.R. 621.

2. The Parliamentary Commissioner for Administration was established by the Parliamentary Commissioner Act 1967, and is statutorily charged with investigating complaints of "injustice" as a result of "maladministration" by central government departments - 5.5 of 1967 Act.

3. In fact the current Commissioner refers to the title "Parliamentary Commissioner for Administration" as his "Sunday title", - see "The Powers, Work and Jurisdiction of the Ombudsman" First Report of the Select Committee on the PCA 1993/94, H.C. 33-I at para.26.

4. An ombudsman would accept complaints directly from the public, see infra. n.8. The Parliamentary Select Committee on the PCA has recommended that the title, "Parliamentary Ombudsman", be adopted - see First Report 1993/94 ibid. para 26.

5. S.10(4) of the 1967 Act.

6. The CLAs are charged with the same task in relation to local government. In England the CLAs report to the "representative body" appointed by the Secretary of State under s.24(1) of the Local Government Act 1974. In Scotland the CLA reports formally to the Commission for Local Authority Accounts in Scotland under s.22(1) of the Local Government (Scotland) Act 1975; and informally to the Convention of Scottish Local Authorities.

7. S.1(3) of the 1967 Act. S.1(3A) allows his removal on the grounds of illness/mental incapacity.

8. For instance see Standing Committee Debates, Standing Committee B, 1st. November, 1966 cols. 84-85, see infra n. 12 \& text; and First Report of the Select Committee on the PCA 1993/94 supra. n. 3 para. 29. 
filter, which requires complaints to be referred only by an M.P. and he reports back to the M.P., not to the complainant. ${ }^{9}$ The enforcement of his recommendations is achieved by means of the Parliamentary Select Committee on the PCA. This evidences a strong connexion with Parliament. The PCA cannot be seen as independent of, and therefore is linked inexorably with, Parliament. In fact it would seem to be difficult to separate the PCA from Parliament without significant statutory changes. This may have significant implications as per the jurisdiction of the courts.

Secondly, as will be seen, the decision calls into question the future role of the Select Committee in monitoring the work of the office.

\section{The PCA and the Courts}

The Parliamentary Commissioner Act 1967, which established the office, was silent of the question of the jurisdiction of the courts in relation to the PCA. ${ }^{10}$ Some indication of the original intentions can be found in the Standing Committe debates on the Bill. ${ }^{11}$ The Minister in charge of the Bill made the following comments in answer to questions about the jurisdiction of the courts:

"We have not here, and deliberately have not, excluded the prerogative writs, but the whole shape of the scheme, as has recently been said, is that the PCA shall be an officer of Parliament, and that he shall be answerable to Parliament and shall report to Parliament. I think that it is generally agreed that a Select Committee will be set up to whom he will report." (emphasis added)

and later,

"Although we have not excluded the prerogative writs, it is right to point out that the fact that we are giving a complete discretion to the PCA to decide whether he takes up a case will make it, I think, in most cases very difficult to mount a successful argument."'I2

Thus, whilst the possibility of review was not deliberately excluded, the concept was that the PCA would be essentially a Parliamentary device. ${ }^{13}$

The courts have adopted an extremely cautious approach. The first attempt to seek review of a decision of the PCA was heard in Re Fletcher's Application. ${ }^{14}$ The PCA

9. S.6(3) \& s.10(4) of 1967 Act respectively.

10. S.9(1) of the 1967 Act states " [i] f any person without lawful excuse obstructs the Commissioner or any officer of the Commissioner in the performance of his functions under this Act, . . . the Commissioner may certify the offence to the Court." This is the only reference to the courts' jurisdiction. This section has never been invoked by the PCA.

11. Supra n. 8 and also for 10th. November, 1966.

12. Supra n. 8 cols. $84-85$.

13. See also White Paper on the PCA 1965 Cmnd. 2767 para. 4

14. [1970] 2 All E.R. 527. 
had refused to investigate the applicant's complaint that the Official Receiver had neglected his duty whilst acting as a liquidator of a company, on the grounds that it was made outwith the time limits as laid down by the 1967 Act. 15

The Court of Appeal, in refusing leave to apply for mandamus, did not give reasons for the decision. When the case went to the Appeal Committee, the applicant was refused leave to take his application to the House of Lords. Lord Reid stated that there was no jurisdiction to order the PCA to investigate due to the nature of the discretion granted under the relevant section of the Parliamentary Commissioner Act 1967.16 The decision of the Appeal Committee left open the possibility of review on different grounds or by different writs. On the whole, it appeared that they believed that review, if possible, would be a rare occurrence. No further reasons were given. No consideration appears to have been given to whether there was a basic jurisdiction to review the office itself, in light of the PCA's constitutional position.

After the decision in Fletcher, no further applications were made in respect of the PCA until 1990. In contrast, the decisions of the CLAs were declared subject to judicial review. ${ }^{17}$

Academic opinion was that the PCA might also be made subject to review following these decisions. ${ }^{18}$ Many commentators saw no reason why the PCA should not be the subject of review. A belief was expressed that, at least, questions as to his jurisdiction would be reviewed as a result of the PCA's powers to report obstructions of his investigations to the courts. ${ }^{19}$ Under the Act, a person who is reported for obstruction may show as a defence that he has a "lawful excuse". It may be that a "lawful excuse" would be that the PCA has no power to investigate this complaint. It is submitted that allowing a person to show that they have a "lawful excuse" for obstructing the PCA as a defence, is different from seeking direct review of a decision. Although a certain inference may be drawn, it does not follow automatically.

There was more caution as to the extent to which the courts would interfere with decisions taken under his discretionary powers. ${ }^{20}$ Interestingly enough, Sir Cecil Clothier, when the incumbent of the office of the PCA, expressed the view that the PCA's discretionary powers would be open to review, as opposed to only matters relating purely to his statutory jurisdiction. ${ }^{21}$

15. See s.6(3) of 1967 Act.

16. Ibid; see also C.Clothier, "Legal Problems of an Ombudsman" 81 L.S.Gaz. 3108 at 3109 where he elaborates on Lord Reid's judgment.

17. See Re a complaint against Liverpool City Council [1977] 2 All E.R. 650; R. v. Local Commissioner for Administration, ex parte Bradford Council [1979] Q.B. 287; R. v. Commissioner for Local Administration, ex parte Eastleigh Borough Council [1988] 3 All E.R. 15]; \& R. v. Commissioner for Local Administration, ex parte Croydon London Borough Council [1989] 1 All E.R. 1033.

18. See Alastair R. Mowbray, "A Right to Official Advice: The Parliamentary Commissioner's Perspective" [1990] P.L. 68 at 87.

19. Supra. n. 10; and also Paul Jackson "The Work of the Parliamentary Commissioner for Administration" [1971] P.L. 36 at 46.

20. Jackson, ibid; see also David Foulkes, "The Discretionary Provisions of the Parliamentary Commissioner Act 1967"' [1967] 34 M.L.R. 377 at 392; \& A.W. Bradley, "The Role of Ombudsman in Relation to Citizens' Rights" [1980] C.L.J. 304 at 309

21. C.Clothier, supra. n.16. 
In 1990, another attempt was made to seek review of the PCA's decision not to undertake an investigation. In $R$. v. Parliamentary Commissioner for Administration, ex parte Lithgow and another, ${ }^{22}$ the applicant sought leave for judicial review of the PCA's refusal to investigate his complaint about the payment of compensation under the Aircraft and Shipbuilding Industries Act 1977. There were a number of grounds of dispute as to whether it was an appropriate complaint for the PCA. These included whether it was in fact a contractual or commercial matter and therefore, excluded by statute;23 whether the matter could have been referred to arbitration, thus providing a legal remedy, ${ }^{24}$ and finally whether or not the complaint was time-barred as it was over ten years old. ${ }^{25} \mathrm{Mr}$. Justice Macpherson refused leave on the basis that the application was itself time-barred by Order 53 rules (it being over fifteen months since the PCA's original decision) and, was not, in his opinion, a case which warranted the exercise of the available discretion.

As to the wider question of whether or not the PCA was subject to review, he offered the following observations:

"I have not been certain that it would be right that the Parliamentary Commissioner should have questions as to his jurisdiction investigated by this court unless the matter could be said ever to fall within the principles of Wednesbury unreasonableness (See Associated Provincial Picture Houses v. Wednesbury Corporation [1948] 1 K.B. 223, [1947] 2 All E.R. 680). If that happened, and if it could ever be suggested that the Ombudsman had been perverse, perhaps different considerations might apply."'26

The judge was not certain that even then the PCA would be within the ambit of the court's jurisdiction. He believed that this was a central issue to which the court would have to return in the future.

\section{The Dyer decision}

The opportunity arose in the Dyer case. The substantive grounds for challenge were not successful. Ms. Dyer mounted three claims. The first was that the PCA had been wrong not to reopen her case on her request, after his report had been submitted. The Court held that the PCA was unable to reopen a case in those circumstances, unless a further referral was made by an M.P., under s.5(1) of the 1967 Act.

In rejecting the second point, that the PCA was not entitled to limit the scope of his investigations to selected areas of the complaint, the Court observed:

22. 26th. January, 1990, QBD, LEXIS Transcript.

23. S.5(3) \& Schedule 3 of 1967 Act.

24. See s.5(2) of 1967 Act.

25. See s.6(3) of 1967 Act.

26. Supra. n.22. Part of this extract was quoted in the PCA's Annual Report for 1991 H.C. 347 (1991/92) para.9.2 
" $[\mathrm{N}] \mathrm{o}$ investigation should be expected to solve all problems for all time and it cannot in my judgment be said that the approach adopted here by the PCA was not one properly open to him." 27

Finally the Court rejected the suggestion that the PCA's practice of sending a draft report to the department concerned but not to the complainant, was a breach of natural justice. ${ }^{28}$ This practice served three main purposes: to allow inaccuracies to be clarified, ${ }^{29}$ notice is given of the proposed remedy; and to allow the department to warn the PCA of matters which should not be disclosed under s.11(3).$^{30}$ Lord Justice Simon Brown emphasised that it was the department and not the complainant that was subject to possible public criticism, and therefore he could not "conclude that fairness hence demanded that she too be shown the draft report." 31

\section{The Dyer decision and the constitutional position of the PCA}

As to the question of jurisdiction, the judge dismissed arguments put by counsel that the constitutional position of the PCA excluded the jurisdiction of the courts.

One of the main considerations must be that the courts are prevented from challenging "proceedings" in Parliament by the Bill of Rights $1688 .{ }^{32}$ The question must be to what extent do the PCA's investigations amount to "proceedings". In addition to the earlier indications of its close associations with Parliament, ${ }^{33}$ it is informative to note that $\mathrm{s.10}(5)$ of the 1967 Act grants the PCA absolute privilege as regards his reports and correspondence with complainants, similar to the position for other "proceedings". However, this is limited to the law of defamation, and therefore cannot be argued as an immediate bar to judicial review.

Lord Justice Simon Brown dismissed the constitutional arguments, stating:

"Many in government are answerable to Parliament and yet answerable to the supervisory jurisdiction of this Court." 34

It is unfortunate that the judge did not expand upon this statement. As it stands it is open to the interpretation that he misunderstood the position of the PCA, equating

27. Supra. n.1 at 383 .

28. There is statutory requirement to send the report to the department - s.10(2) of 1967 Act. However, the PCA is also given discretion as to how he conducts his inquiries - s.7(2) of 1967 Act. It is submitted that he could decide to send a draft report to the complainant via the M.P. even in the absence of a statutory requirement.

29. This is to prevent a recalcitrant department claiming before a Select Committee hearing that the report is inaccurate.

30. S.11(3) of the 1967 Act allows the relevant Minister to give notice that information, if disclosed, would be prejudicial to the safety of the State, or otherwise contrary to the public interest.

31. Supra. n.1 at 384.

32. Article 9 states "That the freedome of speech and debates or proceedings in Parlyment ought not to be impeached or questioned in any court or place out of Parlyment."

33. Supra. ns.5-13 \& text.

34. Supra. n.1 at 380 . 
him with the government departments he investigates. Yet he is an officer of Parliament, and independent of government. Presumably, it was meant to imply that even although a government department is answerable to Parliament, it does not preclude the court's jurisdiction.

This still does not really solve the problem of whether the PCA's investigations are "proceedings" in Parliament. A government department and its activities clearly does not fall under this term. Unfortunately argument does not seem to have been taken on the direct point of the application of the Bill of Rights to the PCA.

A narrower submission on the court's jurisdiction was also rejected. It had been argued that the courts could only review the PCA's discretion in cases of extreme abuse of that power. ${ }^{35}$

It would appear that the Court had accepted no restrictions on its powers of review. Yet, Lord Justice Simon Brown went on to state that:

\begin{abstract}
"[I] toes not follow that this Court will readily be persuaded to interfere with the exercise of the PCA's discretion . . . Bearing in mind too, that the exercise of these particular discretions inevitably involves a high degree of subjective judgment, it follows that it will always be difficult to mount an effective challenge on what may be called the conventional ground of Wednesbury unreasonableness." "36
\end{abstract}

This mirrors the position envisaged in the Standing Committee reports. ${ }^{37}$ It is perhaps possible to see this decision in a wider context as one of a number of recent decisions which have extended the ambit of judicial review to peripheral functions of Parliament. ${ }^{38}$ Whether this is a reaction to a perceived impotency of the legislature, in view of its virtual control by the executive, combined with the length of administration by the current government, is yet to be seen. It could be a very interesting development in the relationship between the courts and Parliament.

\title{
Further implications of the Dyer decision
}

There are many other implications from the decision in Dyer. In relation to the office, it opens the potential for review of decisions in a number of areas. There may well be questions as to whether the PCA has exceeded his jurisdiction. There

35. Nottinghamshire County Council v. Secretary of State for Environment (1986) A.C. 240 \& R. v. Secretary of State for Environment, ex parte Hammersmith \& Fulham London Borough Council (1991) 1 A.C. 521 were cited in support of this argument. This is a similar argument to those used by earlier academic commentators - supra. n.20.

36. Supra. n.1 at 381.

37. Supra. ns. 8 \& 11.

38. For example R. v. Ecclesiastical Committee of Both Houses of Parliament, ex parte The Church Society, 22nd. October, \& 28th. October, 1993, The Times, 4th. November, 1993; The Independent, 4th. November, 1993. Consider also the warning by the Speaker on 21 st. July, 1993, (Hansard 6th. Series vol.229, cols.351-352), in light of the possible arguments to be raised in $R$. v. Secretary of State for Foreign Affairs, ex parte Rees-Mogg [1994] Q.B. 552; [1994] 2 W.L.R. 115; [1994] I All E.R. 457]. 
may also be fertile ground in the areas where he holds discretionary power. For example, the PCA has a statutory discretion as to acceptance of cases where other remedies are available to the complainant. ${ }^{39}$ This aspect of his powers was certainly viewed by Sir Cecil Clothier as a possible target for judicial review. ${ }^{40}$

Further questions might be raised as to the PCA's investigative procedure, and whether or not the requirements of natural justice have been met. The PCA's office will be happy enough with the decision in Dyer on this point, as it lends legal weight to their established practice in this matter. Despite criticism by writers such as Burgess, the office has always maintained that it would be a pointless exercise to send a copy of the draft report to the complainant. ${ }^{41}$ The main purposes have already been noted. ${ }^{42}$ It is argued that the complainant's side of the matter will have already been supplied and any omissions or inconsistencies investigated. It appears that the office fears a protracted correspondence with the "professional" complainants that they sometimes attract. It is impossible to tell how much dissatisfaction is caused by this procedure, as there has been little work in the study of the complainant's reaction other than Burgess. ${ }^{43}$

An unarguably negative consequence of this decision may be the increased length of investigations, particularly if the department concerned seeks to challenge the PCA's decision to investigate.

The other major question arising in light of the Dyer decision is where does this leave the Select Committee on the PCA. ${ }^{44}$ For many years this Committee has served as a form of appeal/review from the PCA's decisions as to whether or not to investigate a complaint. If an M.P. or complainant is unhappy with the outcome, they are usually referred to the Select Committee. The Committee will investigate the complaint and can call the PCA to account for his decision. If the courts are now going to share this role, it may be tempting for the dissatisfied complainant to seek the judicial option. It will cause a certain amount of confusion. It could also lead to an indirect clash between the Select Committee and the courts, if they arrive at opposing views as to the correctness of the PCA's conduct of the investigation.

The Select Committee could find its attempts to force a recalcitrant department to provide a remedy might be hindered by the department seeking judicial review of the PCA's decision.

\section{S.5(2) \& (5) of 1967 Act.}

40. Supra. n.16. Also Woolf L.J. stated that he would not find it unsatisfactory if the CLA did not investigate a complaint for which there might be a remedy by way of judicial review $-R$. $v$. Commissioner for Local Administration, ex parte Croydon London Borough Council supra. n. 17 at 1045 - this would apparently effectively fetter the CLA's discretion in this matter.

41. Paul Burgess, "Whose side is the ombudsman on?" (1983) 63 New Society 55. The article is much refuted - see W.K. Reid, "What's the good of law in a case o" the kind?" [1993] P.L. 221 at 222. For comment on this aspect of the Dyer decision see Norman S. Marsh, "The extent and depth of judicial review of the decisions of the Parliamentary Commissioner for Administration" [1994] P.L. 347.

42. Supra. ns. 28-31 \& text.

43. The Select Committee on the PCA has called for a complainant satisfaction survey - supra. n.3 at para. 23. It is not clear what changes would be made in light of any such survey as a result of the decision in Dyer. The office has had a practice of sending a draft report to a complainant, or a third party who is criticised in the report, to allow an opportunity for comment. 
Further, the question remains that now the PCA could be said to be truly in the legal domain, it may not be long before pressure mounts to grant the PCA statutory powers of enforcement. The granting of enhanced powers to the CLAs has been widely regarded as a success. ${ }^{45}$ Although it must be remembered that they did not have the benefit of a device such as the Select Committee. If the PCA were to be granted such powers, one of the primary functions of the Select Committee would become largely irrelevant.

\section{Conclusion}

The Dyer decision represents the legal "colonization" of another essentially nonlegal redress mechanism. This is despite the trend towards the concept of alternative dispute resolution, of which the PCA was a prime, public law example. As has been seen, the PCA was designed to aid M.P.s in their scrutiny of the Executive. It was not intended to be a "legal" device, but to remedy maladministration, and improve administration in general, thus preventing recurrent problems. The effect of the Dyer decision may well be the importation of more legal concepts into the process, and a move away from the concerns of efficient administration. This may well distract from considering the complaint in terms of good or maladministration. The PCA has successfully balanced the needs of the administration, with the needs of the individual, and has remained a unique unit, supervised by the Select Committee. It would be unfortunate if such a successful alternative redress mechanism as the PCA became merely an adjunct to, or an informal tier, of the legal system, rather than an institution equal to the courts in status, but concerned with different issues. 